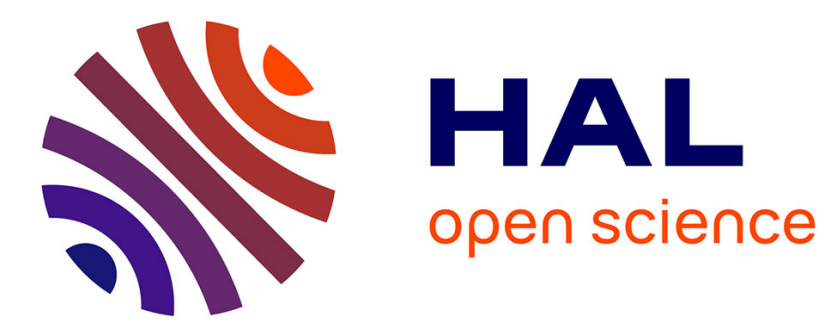

\title{
Administering Systemic Risk vs. Administering Justice: What Can We Do Now that We Have Agreed to Pay Differences?
}

\author{
Pierre-Charles Pradier
}

\section{- To cite this version:}

Pierre-Charles Pradier. Administering Systemic Risk vs. Administering Justice: What Can We Do Now that We Have Agreed to Pay Differences?. Accounting, Economics and Law: A convivium, 2011, pp.Article 10. 10.2202/2152-2820.1015 . hal-00605180

\section{HAL Id: hal-00605180 \\ https://hal-paris1.archives-ouvertes.fr/hal-00605180}

Submitted on 30 Jun 2011

HAL is a multi-disciplinary open access archive for the deposit and dissemination of scientific research documents, whether they are published or not. The documents may come from teaching and research institutions in France or abroad, or from public or private research centers.
L'archive ouverte pluridisciplinaire HAL, est destinée au dépôt et à la diffusion de documents scientifiques de niveau recherche, publiés ou non, émanant des établissements d'enseignement et de recherche français ou étrangers, des laboratoires publics ou privés. 


\section{Administering Systemic Risk vs. Administering Justice: What can we do now that we agreed to pay differences?}

Professor Stout brilliantly addresses both the ideological content of economics and a real-world problem at the same time. On the ideological side, Professor Stout recalls the time where the first "economists" gave a fresh new look on a matter that belonged so far to ethics. Bernard Mandeville and Adam Smith derailed the pre-Enlightenment common sense, showing that socially useful action should not necessarily derive from virtue. Hence their paradoxical praise of greediness and speculation that, if morally abject, benefited the commonwealth. Their demonstration inherited somewhat of Machiavelli's provocative rhetoric: since then, morality argument seemed irrelevant in economics, and many a citizen was disappointed by how cynic economists can be. Professor Stout restored a moral perspective on economics, showing that not every form of greediness is useful: if "by pursuing his own interest" the speculator can contribute to the ruin of all; then such action should be reputed immoral.

How immoral? Here's the real-world problem: speculation, if fuelled only by disagreement about (the likelihood of) future events, leads to a zero-sum game that both distract workforce from socially useful activity and raises systemic risk. As a ban on derivative instruments would deter the "useful" speculation, Professor Stout suggest to raise the common law tradition, where the gains arising from pure betting are not publicly enforceable. In the end, something of this tradition could be recognized in the Dodd-Frank Act.

I must confess I fully agree with the first part of the demonstration - economic paradoxes can obscure a problem as much as individual morality, we cannot be satisfied with a partial equilibrium reasoning - but I think some generality might be added to the second one.

The demonstration that we should do something to prevent the collapse of the financial system might seem incomplete to economists, who are used to review articles surveying all theoretical arguments (Capelle-Blancard 2009), or empirical studies (Mayhew 2001). This is precisely where the argument is brilliant: as a priori reasoning about speculation is inconclusive, the point is whether disagreement based speculation is now a risk of systemic significance. Professor Stout suggests a measure of "speculation systemic riskiness" as a leverage ratio (notional amount of derivatives contracts divided by amount outstanding of underlying). The current value of this measure shows the underlying risk is covered more than 4 times. This suggests that derivatives are not used as insurance, but for speculation of the perverse kind (i. e. disagreement based). Unfortunately, Stulz [2004], p. 178-9 has 
shown how the notional amount can be biased. The measure cannot then be reputed fully reliable, although it indicates that moral hazard produced by individual speculative behaviors (of firms and people) are of systemic significance.

Once we agreed on that premise, Professor Stout cites the common law principle not to enforce debts that derive from bets. In fact, this is not just a common law principle: it is a general law principle in Western Europe since the Roman Republic. As an example of continental law, the French Code Civil featured the famous article 1965 - "the law does not enforce any debt related to gambling or betting" - which was opposed to derivative transactions resulting in "paying differences". It should then be recalled that this "gambling exception" was relaxed earlier in continental Europe than in common law countries: (Riva-Lagneau Ymonet 2010) Italy in 1873-75; France in 1885; Germany in 1896, the Netherlands in 1903 and the United Kingdom in 1909... and 1974 in the United States! How was it possible that the financially archaic countries of Europe relaxed the Roman law principles sooner? There is a simple answer: the underlying assets (stocks and bonds) on which to build up derivatives ought to be authorized first in Europe. As a consequence, Lagneau-Ymonet and Riva (2010) have shown that the 1885 reform in France played a significant role in adding liquidity and stabilizing the market after the turmoil of 1882. Why not then generalize this a priori authorization? Marteau and Morand (2010) asked whether one should

"create an authority, such as the FDA in the United States, in charge of authorizing the emission of derivatives [in absence of clearing chamber or when the condition of replicating by arbitrage is impossible]" (p. 50-51)

An alternative to the common law rule might then be an a priori decision of a relevant authority.

This possibility has to be emphasized, because Professor Stout does not consider it. Moreover it is not a purely fictitious hypothesis: we all remember how the SEC forbade short selling in September 2008, precisely to avoid destabilizing speculation against the banks. Then some countries maintained the ban to fight speculation against sovereign debt of states distressed by the financial crisis. As Riva and Lagneau Ymonet have shown, speculation using short selling is a special case of disagreement based speculation: a short seller communicates to the market that she evaluates the stock less than the buyer, but without implying that each holder of the same stock evaluates it at the same price (as it is theoretically the case in a "covered" transaction). The short seller takes her risky positions in order to make a profit by the repurchase at lesser cost, hence the short seller must find a bolder who evaluates the stock at a lower price than the one of her sale. One can argue, then, that short selling, although is does look like a spot transaction, is in fact a special case of derivative trading (see e. g., FDA [2009] p. 7: "For example, a short position can be taken through single stock futures, index futures and options, spread bets, CFDs and total return swaps (based either on a particular share or on an index).”). 
Agreeing to this statement only makes the question more compelling: why then forbid short selling and let the alternative derivative forms of trading continue? Why not ask for a preliminary authorization of every single derivative instrument (not traded via organized exchanges nor amenable to unambiguous marking to model)?

Professor Stout overlooks that possibility and concentrates on the relics of the common law principle visible in the Dodd-Frank Act

"the bill requires that swaps and other financial derivatives that do not hedge against a 'commercial risk' must be traded, if they are traded at all, on a registered exchange or a "clearinghouse" that performs a similar private enforcement function..."

Although this looks like the old common law principle, it must be emphasized here that the modus operandi here is very different: the differences contract is valid and enforceable. Only the rise in transaction costs might deter perverse speculators ${ }^{1}$. Firms in need of a genuine hedge will be ready to pay for it, hence they might find as counterparty a speculator of the "useful" type. The principle is then used metaphorically. As in Europe, no court will have to decide whether differences should be paid: there is simply too much at stake (not just the value of a deal but the consequences for the whole industry of a court decision). In consideration of the potential consequences, the administration of justice, as inherited from the common law principle, has then been replaced by administration of systemic risk.

In the current setup, the Financial Stability Oversight Council created by the Frank-Dodd Act has extended and discretionary powers to monitor both financial instruments (section 120) and financial corporations (section 113). Section 120 enables the Council to "provide for more stringent regulation of a financial activity by issuing recommendations to the primary financial regulatory agencies to apply new or heightened standards and safeguards". Although this might seem vague, the interpretation by Skadden et al. is clearly that the Council might rule out a financial instrument by raising transaction costs. The termination issue is even explicitly addressed by section 115 as the Council might exact a "resolution plan". One might then say that the Frank-Dodd Act is ahead of the Europeans' expectations: instead of relying on one-shot prior authorization as called for by Marteau and Morand, the American regulation introduces a discretionary authority with hardly limited powers

\footnotetext{
${ }^{1}$ See e. g. Skadden, Arps, Slate, Meagher \& Flom p. 55: "market participants could be affected by increased costs and increased regulatory oversight and reporting. The impact on some thinly capitalized, leveraged investment funds and structured finance vehicles could be significant and may make certain structures unfeasible."
} 
over instruments and firms. It might not be that easy to deal with both the responsibility for acting discretionarily and the "too big to fail" issue when acting a posteriori. No doubt that the typology of speculation and the common-law principle recalled by Professor Stout will prove extremely useful to vindicate the Council's future interventions.

\section{Additional References}

Capelle-Blancard G. 2009, les marchés dérivés sont-ils dangereux ?, Revue Economique, 2009/1 (Vol. $60)$.

Financial Service Authority (2009), Short Selling, Discussion paper, 09/1, February 2009. Paul Lagneau-Ymonet, Angelo Riva (2010), "The Ambiguities of Short Selling: Liquidity or Speculation? Lessons from the Nineteenth Century Paris Bourse", SSFA Seminar paper. Marteau D., Morand P., (2010), Normes comptables et crise financière, Rapport au Ministre de l'Economie, de l'Industrie et de l'Emploi publié à la Documentation française Mayhew S., 2001, The Impact of Derivatives on Cash Markets: What Have We Learned? Working Paper, University of Georgia.

Stulz R.M., 2004, Should We Fear Derivatives?, Journal of Economic Perspectives, Volume 18, Number 3-Summer 2004-Pages 173-192. 